\title{
Extraction, Characterization and Dextrinization of Starch from Six (6) Varieties of Tubers from Iwo Osun State Nigeria for Application in the Production of Adhesives
}

\author{
Oluwatobi David Adekunle, Omiye Mobolaji Kayode, Oluwatoyin Kemi Awoyale, Modupe Dawodu
}

Department of Chemistry and Industrial Chemistry, Bowen University, Iwo, Nigeria

Email address:

david.adekunle@bowenuniversity.edu.ng (O. D. Adekunle)

\section{To cite this article:}

Oluwatobi David Adekunle, Omiye Mobolaji Kayode, Oluwatoyin Kemi Awoyale, Modupe Dawodu. Extraction, Characterization and Dextrinization of Starch from Six (6) Varieties of Tubers from Iwo Osun State Nigeria for Application in the Production of Adhesives. American Journal of Chemical and Biochemical Engineering. Vol. 3, No. 2, 2019, pp. 7-11. doi: 10.11648/j.ajcbe.20190302.11

Received: September 17, 2019; Accepted: October 9, 2019; Published: December 4, 2019

\begin{abstract}
Tuber crops are widely consumed; they come in various varieties with great nutritional and non- nutritional values. They are very rich in starch. The starch content of each of the six varieties of Nigerian tubers was determined, each of the tubers was wet fractionated in the laboratory and the starch was recovered. The composition of the tubers (dry matter, protein, ash and mineral content) and starch isolation (moisture, starch, protein, phosphorus, fat and carbohydrate) were determined. Substantial differences in the starch content of the tubers were observed. The dry starch recovery ranged from $10.20 \%$ to $18.30 \%$ and the wet starch recovery ranged from $15.70-32.40 \%$. Moisture content ranged from $13-15.80 \%$, viscosity $275.08-382.33$. The carbohydrate, ash, fat and protein content of the six varieties of the tubers vary from $45 \%$ to $53.8 \%, 1.0$ to $2.0 \%, 19.56$ to $21.99 \%$ and $10.96-14.29 \%$ respectively. All six starches were insoluble in water and ethanol and proved positive to iodine and Fehling's test. Extracted starch was dextrinated using $0.1 \mathrm{M}$ and $0.2 \mathrm{M} \mathrm{HCl}$ separately at 160 and $100^{\circ} \mathrm{C}$ to obtain yellow dextrin and white dextrin respectively which were soluble in water. Modified starches were formulated into adhesives. Results obtained indicated satisfactory strength for the adhesives. Thus starches suitable for the production of adhesives were obtained.
\end{abstract}

Keywords: Dextrinization, Starch, Tuber, Adhesive

\section{Introduction}

Tuber crops are widely consumed and they come in various varieties with great nutritional and non- nutritional values. Tuber crops being a rich source of carbohydrate has encouraged its consumption, the non-food applications of tuber crops due to its starch content have promoted the preferential use of starch in industries to other polysaccharides [1]. Tropical root and tuber crops are a pertinent source of food security since they are climatic resilient and can grow on less productive and marginal lands. In addition, productivity is higher in comparison with cereals and horticultural crops, constituting a source of income for farmers [2] they are cultivated in almost all parts of the world and it is quite cheap and a readily available raw material for adhesive production [3].

Starch is the most significant form of carbon reserve in plants in terms of the amount made, the universality of its distribution among different plant species, and its commercial importance. It consists of different glucose polymers arranged into a three- dimensional, semicrystalline structure-the starch granule [4]. Since it is one of the most abundant natural carbohydrate polymers and is nonallergenic, it is generally recognized as safe (GRAS), and low-cost [5] thus the reason why it finds application widely.

Starch is synthesized transiently in organs, such as leaves, meristems and root cap cells, but its major site of accumulation is in storage organs, including seeds, fruits, tubers, and storage roots [4].

Starch, the food reserve homopolysaccharide of plants [6], is a biocompatible, biodegradable, nontoxic polymer [7], which occurs widely in nature and commonly used [8].

The application of starch includes in adhesives, agrochemicals, cosmetics and toiletries, detergents, paper 
making additives, pharmaceuticals, paints, textiles, water purification, biodegradable plastics and as super-adsorbent materials to mention a few, partly because of the wide range of functional properties such as gelatinization, pasting, retrogradation, water absorption capacity, swelling power, and solubility derived from it in its various natural and modified forms, and partly because of its low cost relative to alternatives [9]. The functional properties vary considerably from one botanical source to another [10], with variety and environmental conditions [11], composition and structures of the starches, which include amylose/amylopectin ratio, crystalline structure, granular size, molecular weight of the starches and chain length distribution of amylopectin [12]. Starch is principally a constituent of some kind of adhesive [3]. Modification of these starches will increase their chances of finding more applications especially in the industries for a variety of applications. The process of modification may be physical or chemical. The physical modification which does not involved any chemical reaction of starch with a modifying reagent is referred to as physical modification of starch and the products are known as physically modified starches. However, most modifications of starches are performed through chemical processes. The chemical reactions of starch (hydrolysis, esterification, etherification, oxidation and cationization) are generally exploited in the industry to produce converted or modified starches fit for different purposes in the industry [13]. It has been proven that starch, especially starches from yam show large variability in their physicochemical and functional properties hence can have diverse applications in both food and nonfood industries [14] therefore dextrinization can create a variety of useful products such as starch with greatly increased water solubility [15].

\section{Methodology}

\subsection{Collection of Materials}

Freshly harvested tubers were obtained from Odo Ori market in Iwo Local Government Area Osun State Nigeria and studied namely:

i. Freshly harvested (Manihiot esculanta)

ii. Fermented cassava (Manihiot esculanta)

iii. Two varieties of cocoyam (Xanthomonas; white and red cocoyam)

iv. Sweet potatoes (Ipomea batatoes)

v. Bitter yam (Discora sp; locally called Esuru)

\subsection{Preparation of Materials}

The freshly harvested tubers were washed with distilled water and barks peeled off manually with a knife without losing the cortex. The peeled tubers were washed, grated and weighed the same day they were harvested. $500 \mathrm{~g}$ of the cassava was allowed to ferment for $24 \mathrm{~h}$.

\subsection{Extraction of Starch}

A fine sieve was used to separate the starch granules from the fiber; the residue was washed with distilled water severally.

The extracted starch was allowed to settle, then the supernatant was decanted off and the starch was washed with fresh clean was to remove the proteins. The starch cake obtained was dried in the sun. The white cocoyam and bitter yam took longer to dry. The weight of the dried starch for each tuber was determined and stored in airtight containers.

\subsection{Physical Measurements of Starch Extracts}

i. Solubility test

One (1.0) g of each extracted starch sample was dried at $80^{\circ} \mathrm{C}$ in an oven for $12 \mathrm{hrs}$. Then to each sample, $5 \mathrm{ml}$ of distilled water was added inside a $50 \mathrm{ml}$ beaker and $5 \mathrm{ml}$ ethanol separately. The mixture was stirred gently, then vigorously and allowed to stand for $12 \mathrm{hrs}$.

ii. Moisture content

In a dry and pre-weighed crucible, $5.0 \mathrm{~g}$ each starch extract was introduced and placed in an oven for $6 \mathrm{hrs}$ at $100^{\circ} \mathrm{C}$, then cooled in a desiccator and weighed. This process was repeated until as constant weight was obtained. The percentage moisture content was calculated using the equation given below.

$$
\% \text { moisture }=\frac{\text { weight loss }}{\text { weight of sample }} \times 100
$$

iii. Determination of crude protein

The micro-kjedahl method was used for the determination of the crude protein function of nitrogen

iv. Determination of $\mathrm{pH}$

The $\mathrm{pH}$ f the extracted starch was determined by a $\mathrm{pH}$ meter using $\mathrm{BDH}$ buffer tablets $(\mathrm{pH} 4$ and $\mathrm{pH} 10)$ to standardize the $\mathrm{pH}$ meter before actual measurements at room temperature.

v. Determination of crude fat

Crude fat was extracted from the starch samples using nhexane in a soxhlet extractor. $5.0 \mathrm{~g}$ of starch was used, extract was separated from solvent using a rotary evaporator and the fatty residue was weighed and \% Fat was calculated using

$$
\% \text { Fat }=\frac{\text { Loss in weight of sample }}{\text { Original weight of sample }} \times 100
$$

vi. Determination of carbohydrate content

This was determined by difference using the equation given below

$\%$ Carbohydrate $=100-($ Moisture $+\mathrm{Fat}+$ Ash + Protein)\%

vii. Determination of mineral content

The mineral content was determined using an Atomic Absorption Spectrophotometer (AAS) after digesting the starch samples. The elements determined are Phosphorus, Iron, Zinc, Sodium, Lead, Copper, Calcium, Magnesium and Manganese.

viii.Determination of acid factor measurement

The quantity of $0.1 \mathrm{M} \mathrm{HCl}$ required for $25.0 \mathrm{~g}$ suspension to get a $\mathrm{pH}$ of 3.0 is referred to as acid factor. Freshly prepared $0.1 \mathrm{M} \mathrm{HCl}$ was titrated against $25 \mathrm{~g}$ each of oven dried starch, 
stirred in $50 \mathrm{ml}$ of distilled water in $250 \mathrm{ml}$ conical flask until pH 30 was obtained.

ix. Determination of viscosity

Three $3.0 \mathrm{~g}$ on $100 \%$ dry matter basis of starch was weighed into a canister which was inserted into the viscometer to measure the viscosity.

Calculation of dried sample weight

Since at $100 \%$ dry matter, $3 \mathrm{~g}$ of starch is required, R Visco Analysis Weight $=$ Sample dry matter

Therefore RVA WT- $3=$ Y

Volume of water $=25 \mathrm{ml}-\mathrm{Y}$

\subsection{Qualitative Tests on Starch Extracts}

i. Fehling's test for reducing sugars

$0.1 \mathrm{~g}$ of each sample was weighed into a test tube; $2 \mathrm{ml}$ of $0.5 \mathrm{M} \mathrm{HCl}$ was added and warmed for 2 minutes after which a few drops of Fehling's solution were added.

ii. Iodine test

$0.1 \mathrm{~g}$ of each extracted starch was weighed into a beaker and $100 \mathrm{ml}$ of boiled water and stirred to give a clear solution allowed to cool and 3-4 drops of iodine solution was added.

\subsection{Quantitative Chemical Tests on Starch Extracts}

\section{i. Determination of total ash content}

$5.0 \mathrm{~g}$ of starch sample was ashed in a muffle furnace at $525^{\circ} \mathrm{C}$ for $2 \mathrm{hrs}$, cooled and weighed. The percentage ash was calculated using the relationship.

$$
\% \mathrm{ash}=\frac{\text { Weight of reidue in } \mathrm{gram}}{\text { Weight of sample in } \mathrm{gram}} \times 100
$$

\subsection{Dextrin Production}

This process was carried out in four steps

i. Acidification

Starch samples were dried in oven to reduce moisture content to about $12.5 \%$, then $25.0 \mathrm{~g}$ of each sample was weighed into a $100 \mathrm{ml}$ beaker for yellow dextrin and $5 \mathrm{ml}$ of $0.2 \% \mathrm{HCl}$ was added drop-wise at intervals with vigorous stirring to ensure uniformity. $2.5 \mathrm{ml}$ of $0.1 \% \mathrm{HCl}$ was used instead for white dextrin

ii. Pre-drying

The acidified starch samples were air dried in the laboratory for $24 \mathrm{hrs}$

iii. Conversion

The pre-dried acidified starch samples were placed in $200 \mathrm{ml}$ beaker and heated in an oil bath for $18 \mathrm{hrs}$ at $160^{\circ} \mathrm{C}$ $\left(100^{\circ} \mathrm{C}\right.$ for white dextrin) with continuous stirring.

iv. Cooling: the produced dextrin was introduced into an ice bath for 20 minutes, then stored in a desiccator

\subsection{Qualitative Analysis on Dextrin}

i. Iodine test

Using the same process as was described for starch.

ii. Solubility test

Solubility in ethanol: $10 \mathrm{ml}$ of $95 \%$ ethanol was added to $0.1 \mathrm{~g}$ of dextrin sample and stirred vigorously without heating.

Solubility in water: $1.0 \mathrm{~g}$ of dextrin was added to $5 \mathrm{ml}$ of distilled water with continuous stirring and left for $12 \mathrm{hrs}$.

\subsection{Adhesive Production from Dextrin}

$8.70 \mathrm{~g}$ of dextrin of each sample was weighed inside a beaker. $21.80 \mathrm{~g}$ of water was added and the mixture heated to $70^{\circ} \mathrm{C}$, then $1.50 \mathrm{~g}$ of borax was added and the temperature increased to $90^{\circ} \mathrm{C}$. $2 \mathrm{ml}$ of phenol was added to the mixture.

\section{Results}

The starch from the six (6) tubers are presented in the tables below.

Table 1. Percentage yield of starch from the six (6) tubers, Physical measurement of starch extract, Viscosity and iodine test.

\begin{tabular}{|c|c|c|c|c|c|c|}
\hline Sample & Fresh cassava & $\begin{array}{l}\text { Fermented } \\
\text { cassava }\end{array}$ & $\begin{array}{l}\text { Cocoyam } \\
\text { (white) }\end{array}$ & Cocoyam (red) & Sweet potato & Bitter yam \\
\hline Wet $\%$ starch yield & 32.4 & 30.00 & 20.00 & 15.70 & 25.00 & 30.00 \\
\hline Dry \% starch yield & 18.30 & 17.60 & 11.00 & 10.20 & 15.00 & 16.00 \\
\hline$\%$ Moisture Content & 13.00 & 13.80 & 15.60 & 15.80 & 15.60 & 14.40 \\
\hline $\mathrm{pH}$ & 3.96 & 8.44 & 5.64 & 4.73 & 6.05 & 5.84 \\
\hline Acid factor & 4.60 & 6.00 & 15.50 & 5.40 & 5.90 & 9.00 \\
\hline Peak viscosity value & 303.75 & 382.33 & 306.33 & 229.42 & 306.00 & 275.08 \\
\hline Iodine test and Fehling's test & Positive & Positive & positive & Positive & positive & Positive \\
\hline Solubility in water & Insoluble & Insoluble & insoluble & Insoluble & insoluble & Insoluble \\
\hline Solubility in ethanol & Insoluble & Insoluble & insoluble & Insoluble & insoluble & Insoluble \\
\hline
\end{tabular}

Table 2. Mineral content of starch from the six (6) tubers.

\begin{tabular}{|c|c|c|c|c|c|c|c|c|c|c|}
\hline Sample & $\begin{array}{l}\mathrm{PO}^{4-} \\
\text { PPM }\end{array}$ & $\begin{array}{l}\text { Ca } \\
\text { PPM }\end{array}$ & Mg РPM & К РРМ & Na PPM & Mn PPM & Pb PPM & Fe PPM & Cu PPM & Zn PPM \\
\hline Fresh cassava & 6.12 & 15.06 & 3.43 & 52.33 & 0.41 & 0.25 & 0.32 & 0.40 & 1.80 & 2.83 \\
\hline Fermented cassava & 7.83 & 20.84 & 5.59 & 22.38 & 1.34 & 0.25 & 0.42 & 0.64 & 4.40 & 3.44 \\
\hline Cocoyam (white) & 5.14 & 9.43 & 2.75 & 37.38 & 0.49 & 0.17 & 0.22 & 0.56 & 0.41 & 1.32 \\
\hline Cocoyam (red) & 6.58 & 7.88 & 2.75 & 27.38 & 0.77 & 0.25 & 0.32 & 0.40 & 2.68 & 3.76 \\
\hline Sweet potato & 15.24 & 25.43 & 7.10 & 79.38 & 1.26 & 0.33 & 0.32 & 1.62 & 0.77 & 2.92 \\
\hline Bitter yam & 0.00 & 12.67 & 4.79 & 3377 & 1.49 & 0.33 & 0.42 & 1.05 & 2.58 & 2.89 \\
\hline
\end{tabular}


Table 3. Proximate analysis of starch from the six (6) tubers.

\begin{tabular}{lllllll}
\hline Sample & Fresh cassava & Fermented cassava & Cocoyam (white) & Cocoyam (red) & Sweet potato & Bitter yam \\
\hline \% Ash & 2.00 & 2.00 & 2.00 & 1.00 & 2.00 & 1.00 \\
\% Protein & 13.06 & 10.96 & 14.29 & 13.91 & 12.96 & 11.28 \\
\% Carbohydrate & 50.62 & 53.38 & 47.47 & 44.40 & 51.08 & 50.13 \\
\% fat & 21.32 & 19.86 & 20.64 & 25.09 & 19.56 & 21.99 \\
\hline
\end{tabular}

\section{Discussion}

Starch has found numerous applications; the application of starch in adhesive production is a vital one as the choice of raw material for adhesive production rests squarely on determinants such as cost, availability, convertibility and starch yield.

Starch consists of amylose and amylopectin and from the results obtained it is noted that starch is insoluble in water due to the presence of amylopectin. The percentage of starch recovery from the six tubers ranged from $10.20 \%$ to $18.30 \%$ lowest from Cocoyam (red) highest from fresh cassava.

From table 1, the starch obtained from cocoyam (red) has the highest moisture content $(15.80 \%)$ while that from fresh cassava has the lowest moisture content $(13.00 \%)$.

The $\mathrm{pH}$ varies from 3.96-8.44. The fermented cassava has the highest and the fresh cassava having the lowest.

From table 2, the carbohydrate content of all the tubers is above $45 \%$. However, fermented cassava has the highest percentage of carbohydrate $(53.38 \%)$ and sweet potato $(51.08 \%)$ having a higher percentage of carbohydrate than fresh cassava $(50.62 \%)$.

The white cocoyam has the highest percentage of protein $(14.29 \%)$ than the other tubers, while the red cocoyam has the highest percentage of fat $(25.09 \%)$. Fresh cassava $(21.32 \%)$ has slightly higher percentage of fat than fermented cassava $(19.86 \%)$.

Trace metals analyzed includes $\mathrm{Ca}, \mathrm{Mg}, \mathrm{K}, \mathrm{Na}, \mathrm{Mn}, \mathrm{Pb}$, $\mathrm{Cu}, \mathrm{Zn}, \mathrm{PO}^{4-}$. The concentration of potassium in all the starch is highest of all the minerals analyzed. Followed by Calcium, then phosphorus and magnesium

White dextrins were insoluble in water and ethanol, while the yellow dextrins were soluble in because it undergoes hydrolysis thereby converting the starch to glucose.

Hence it proves positive to Fehling's solution for reducing sugars. White cocoyam gave brown dextrin because it took a loner time to dry. Therefore this reveals that yellow dextrin is soluble in water to give a colourless solution while starch is insoluble in water.

The adhesives produced with the yellow dextrin obtained gave a fairly satisfactory strength. The strengths varied slightly which could be due to non-homogenous acidification, unequal heat distribution amongst other latent factors.

\section{Conclusion}

Adhesives obtained from all the tubers shows an indication that starch obtained from other tubers could be used for industrial production of adhesives. Thus the importance of starch continues to be on the upward trend due to its versatility. Its availability in these six varieties of tubers shows and proves that starch is availability in abundance; starch from tubers has transcended its traditional use as a source of carbohydrate in food to more sophisticated nonfood applications. Its susceptibility to modification, which transforms the native properties into more desirable and malleable characteristics fit for different purposes has led to its growth in modern technological application.

Starches will naturally remain insolubility in cold water and loss of viscosity easily, these 'weaknesses' are lost after modification of starch by dextrinization thus increasing its utilization in industry for the production of value added products

\section{Recommendation}

The dextrinization of starch from tuber should be further researched into so as to provide more applications for the starch from edible and non-edible tuber crops.

\section{References}

[1] Oladebeye A. O., (2014) Physicochemical Characterization of Native, Modified and Nano Starches of Selected Tubers and Seeds Ph.D Thesis.

[2] Saranraj P. S., Behera S. R., Ray C., (2019) Innovations in Traditional Foods Chapter 7 - Traditional Foods From Tropical Root and Tuber Crops: Innovations and Challenges Pages 159-191 https://doi.org/10.1016/B978-0-12-8148877.00007-1.

[3] Opara I. J, Ossi C. D and OkoUdu C. O (2018) Formulation of Cassava Starch-Based Adhesive Int. J. Adv. Res. 5 (7), 26-33.

[4] Cathie M., and Alison M. S., (1995) Starch Biosynthesis the Plant Cell, Vol. 7, 971-985, American Society of Plant Physiologists.

[5] Carlos A., Javier C., Esmeralda R., Ricardo O., Zaira E., Luis D., Fernando M., Fabiola A., Reyna N., (2018) A modified Achira (Canna indica L.) starch as a wall material for the encapsulation of Hibiscus sabdariffa extract using spray drying. Food Research International. Article In press.

[6] Malcolm, P. S. (1990). Polymer Chemistry: An Introduction (2nd Ed.). Oxford University Press, New York. pp 537-69.

[7] Weslen, K. B. and Weslen, B., (2002). Synthesis of amphiphilic amylose and starch derivatives. Carbohydrate Polymers, 47, 303-311.

[8] Whistler, R. L. and Paschall, E. F., (1965 and 1967). Starch: Chemistry and Technology (2nd Ed.). Academic Press, Inc., New York. 
[9] Sanderson, G. R., (1981). Polysaccharides in Foods. Food Technology, 315, 50-57.

[10] Yuan, Y., Zhang, L., Dai, Y. and Yu, J., (2007). Physicochemical properties of starch obtained from Dioscorea nipponica Makino comparison with other tuber starches. Journal of Food Engineering, 82, 436-442.

[11] Chen, Z., Schols, H. A., and Voragen, A. G. J. (2003). Physicochemical properties of starches obtained from three varieties of Chinese sweet potatoes. Journal of Food Science, $68,431-437$.

[12] Lu, T. J., Chen, J. C., Lin, C. L. and Chang, Y. H. (2005). Properties of starches from cocoyam (Xanthosoma sagittifolium) tubers planted in different seasons. Food Chemistry, 91, 69-77.
[13] Egharevba H. O. (2019) Chemical Properties of Starch and Its Application in the Food Industry pages 16-17 DOI: http://dx.doi.org/10.5772/intechopen.87777.

[14] Otegbayo B., Oguniyan D., and Akinwumi O., (2013) Physicochemical and functional characterization of yam starch for potential industrial applications. Starch/Stärke, 65, 1-16.

[15] Suzanne H. (2018) Starch in Food (Second Edition) Chapter 23 - Starch: Physical and Mental Performance, and Potential Health Problems. Structure, Function and Applications. Woodhead Publishing Series in Food Science, Technology and Nutrition Pages 855-871. 